\title{
Learner Teacher Program in Transformative Pedagogical Perspective
}

\author{
Pupun Nuryani \\ Department of Pedagogy \\ Universitas Pendidikan Indonesia \\ pupunnuryani@upi.edu
}

\begin{abstract}
During 2015-2016, Indonesian government was and is aggressively implementing teacher-quality improvement programs. One of them is through the perception-teacher program; this program is a strategic move in response to the score lowness of Teacher's Competency Test in 2015 which only hit 55 on average. Learner teacher program aims to improve the competency of teachers as actors of education who continue to learn in exploring and updating the teaching and learning process in order to educate the young generation who have high quality in order to compete and exist in the 21st century. Learner teacher program has relevance to the human concept in the transformative pedagogy perspective, humans are being which are in the process of becoming, a creature that is not yet complete and continually designing a presence in the world with his work This paper attempts to analyze the learner teacher program as a manifestation of lifelong education in transformative pedagogy perspective. The methods research is qualitative-descriptiveanalytic. This article has significance to strengthening the implementation of learner teacher program as manifestations of improving the quality of teacher competence in Indonesia.
\end{abstract}

Keywords-Learner Teacher Program, Education Policy, Lifelong Learning, Transformative Pedagogy.

\section{INTRODUCTION}

Socio-pedagogical reality is constantly becoming history and having dialectic with the actors of education. Sociopedagogical change is a necessity that cannot be avoided by the education actors and policy makers; it is certainly to be addressed critically and emancipatory, rather than adaptivedogmatic. In facing the 21 st century there are some social changes that would have an impact on changes in education. According to Tilaar [1] "there are at least three forces that trigger changes in the socio-pedagogical; they are Democracy, Development of Science and Technology, and Globalization. The first force is the force of democracy which is a social force in the struggle of human rights for justice that leads to the welfare of the people. Through democracy we expect that the perpetrators will up hold educational interaction, participation and emancipation for the sake of the struggle to develop superior human resources. The second force is the development of science and technology; this is an instrumental rational force which helps human to facilitate their lives in various fields. While globalization is a force that demands the necessity of a superior man which is able to compete in a global world.

These three forces of social-pedagogical triggers of change are certainly implicate the estuary of education which should be oriented towards full debriefing of student competence in facing the 21 st century without setting aside educational element values, morals, culture, and religion. Morocco, et al. [2] argues that in the 21 st century there are four minimum learning competencies that must be mastered; Conceptual understanding, creative thinking, critical thinking, and collaboration and communication. In harmony with that, Trilling \& Fadel [3] revealed that 21st century learning model should be oriented towards equipping the 21 st century competencies which include competencies of life and career skills, learning and innovation skills, and information, media and technology skills. Other than opinions of Trilling \& Fadell, more over Binkley, et al. [4] argued that there are ten musthave skills in the 21st century; they are classified into four competence. The skills are: creative thinking skills, critical thinking, metacognition thinking, communication, collaboration, information literacy, ICT literacy, citizenship skills, work and career skills, as well as individual responsibility and social skills. Those ten skills are essentials basis for one to be able to exist in the life of this century.

Referring to the competencies of the 21 st century which are increasing in terms complexity, of course, those competencies should be in synergy with superior teacher competence and able to face the challenges of the times. In response to the said issue, the Ministry of Education and Culture of Indonesia has launched the learner teacher learners. Starting from the speech of the Minister of Education and Culture in a speech at the Commemoration of 2015's or National Teacher's Day; he invited all teachers to become learner teacher, a teacher which is always present as an educator and leader for learners, teacher who attend to send a message of hope, teacher which are an example of resilience, optimism and cheerfulness. Teacher is a learner who continually learns to improve their quality [5]. In this regard, certainly this nation needs profile of teachers who have the spirit to learn, curiosity which stay sharp in seeing the phenomenon, has an attitude reflective in the transformative learning process that he carried on in class for the sake of a significant improvement in the future. In response, the author was inspired to write an analytical paper on learning teacher program as a manifestation of lifelong education in the transformative pedagogy perspective.

\section{RESEARCH METHOD}

This article is an analytical study of the policy of the Ministry of Education and Culture of the Republic of Indonesia 
on learner teacher program. The author tried to give his views on learner teacher program in transformative pedagogy perspective. The learner teacher program could also be interpreted as a manifestation of lifelong learning. The role of teachers as learners is lifelong learning, spreading the benefits anytime, anywhere through knowledge; learner teacher is an inspiration to whoever met them.

\section{RESULTS AND DISCUSSION}

\section{A. The Nature of Learner teacher}

The importance of the role of teachers in education mandated by the Law of the Republic of Indonesia Number 14 Year of 2005 on Teachers and Lecturers, which mandates their coaching and professional development of teachers as the actualization of a professional educator. The content of UU RI No.14 Year of 2005 is as follow:

"Considering that it would need to be done an attempt to empower and increase the quality of teachers and lecturers in planned, directed, and sustainable way; that teachers and lecturers has the function, role and strategic position in the national development in the field of education as referred to in point a that they need to be developed as a dignified profession"

For the realization of the mandated of the law as intended, the Ministry of Education and Culture implemented Learner teacher Competency Enhancement Program for all teachers, whether they are certified or not certified. Learner teacher is the ideal teacher who continues to learn and develop (upgrade) themselves at anytime and anywhere. Teachers continue to learn and develop themselves not for the sake of government or the head of the school, but it is true that every educator or teacher is a learner. It is only from teachers which continue to learn and work that will emerge a generation of lifelong learners who continuously contribute to the society and environment. Learner teacher is a teacher who always continues to learn as long as he devoted himself in the world of education. Therefore, when a teacher decides to quit or will not learn anymore; at the time he ceases to be a teacher or educator [5].

Teacher is a role model or example for the students so that the initial view of teachers affects the continuity of learning for learners. Teachers may present interesting, motivating, and inspiring learning process from teacher's knowledge and experience which is regularly updated by various positive feedback obtained from various sources of learning. Knowledge and experience can be gained from books, television, cyberspace/internet, educational seminars, and also training and upgrading. In the process of learning, teachers produce enlightening works and innovation to be applied in the learning process of the classroom, so that they may grow all potential learners where they not only can win, but could exceed their goals Teachers are not only a teacher but more than that a teacher is an educator. As an educator, teacher should have a variety of abilities as the competencies required of a professional educator [5].

There are several reasons why a teacher should continue to study for their work as an educator, as follows.
- The teaching profession is a specialized field of work undertaken by the principles of professionalism which has the opportunity to develop in a sustainable manner with the professionalism of lifelong learning.

- The development of science, technology and art requires teachers to have to learn to adapt to new things in current. In this condition, the teachers are required to be able to adapt to the new changes. These capabilities can be obtained through training, seminars and through literal study.

- Learners' character which is always different from generation to generation is a challenge for a teacher. The learning method used in previous generations of learners would be difficult to apply in the current generation of learners. Therefore, the way or the methods of teaching used by teachers must be adapted to the current conditions of learners.

Based on the reasons mentioned above, the learner teachers must continue to learn, able to adapt to change, and can inspire students to become independent responsible, creative, and innovative learners subject [5].

\section{B. The Nature of Learner Teacher in the Perspective of Transformative Pedagogy.}

Transformative Pedagogy is the metamorphosis of critical pedagogy developed by Paulo Freire, Ivan Illich, Steven Mclaren, ec... Transformative Pedagogy for Indonesia was initiated by Prof. H.A.R. Tilaar, M.Sc.Ed. According to Tilaar [1] "Transformative pedagogy is a dynamic pedagogy. Pedagogy is evolving according to the dynamic changing or developments of social and individual changes which are constantly changing. Transformative pedagogy knows no period but only recognizes comma". Referring to the opinion of Tilaar, it can be defined that transformative pedagogy is pedagogy which continue to exist and having dialectic in an ascending manner, create change and innovation in the field of education for the improvement of human resources of superior quality.

The study of human philosophy is an interesting study in the transformative pedagogy perspective. According to Tilaar [1] "human in transformative pedagogy perspective is a being that is always in the process of becoming; human whom can only develop through dialogic interaction, active participatory role, and the role of emancipatory. Humans act as the transcription factors and the influence of social change". In harmony with the view of Tilaar, we can conclude that humans are being which resist passiveness, humans have the energy to maintain their existence, and humans are magmatic which always possess the energy to explode and soar. Humans would not evolve with orders and mechanistic activity. Humans can only develop through dialogic, participatory, and emancipatory interaction in order to name the world, knowing it, read it, and change it.

Study of human philosophy in transformative pedagogy perspective certainly has some implications for the learner teacher program. Indeed teachers are not educational operators, 
whose job is only according to the principals and government orders. Teachers are learners, professionals in education. Teachers should always have a reflective attitude towards various issues or educational phenomena. Based on the problems of education, teachers should become a true magmatic human being; having heat energy to significantly melt the problem. Teachers are human beings who hold their existence is in order to improve themselves dialogically, participatory, and emancipatory. In this case teachers must continue to learn and improve their competence as a professional in the field of education.

\section{Learner Teacher Program}

Learner Teacher Competency Enhancement Program is a process of teaching and learning activities in order to improve the capability and competence of teachers in implementing the tasks of their profession. The enhancement includes several activities aimed at the improvement and the growth of capabilities (abilities), attitude (attitude), and skills (skills). This activity is expected to produce a change in teachers' behavior which significantly changes the behavior impact on improving the performance of teachers at teaching and learning in the classroom [5].

Teachers as learners make Learner Teacher Competency Enhancement Program as one way to meet the standards of teacher competence in accordance with the demands of the profession and the development of science, technology and art. Learner Teacher Competency Enhancement Program became an important part that should always be performed continuously or in a sustainable manner to maintain the professionalism of teachers. Therefore, Learner Teacher Competency Enhancement Program should be designed to provide a new experience to help in improving areas of their appropriate competence for teachers to acquire the knowledge, skills, and improve their attitudes behaviors which is needed to perform their jobs in a well manner in accordance to their responsibilities [5]. General Aims of Learner Teacher Program

The learner teacher competence enhancement program generally aims to improve the competence of teachers, both pedagogically and professionally, as well as their performance as an educator and leader for learners, as an example of resilience, optimism and joy for their students, through various modes and media, in various learning center.

\section{Specific Aims of Learner Teacher Program}

Specifically, the program aims to increase the competence of learner teachers so that they:

- master the pedagogy and professional competence in accordance with the modules studied;

- performing as an educator and leader for learners;

- become an example of resilience, optimism and joy for learners; and

- Having willingness to continue learning to develop their potential.

\section{E. Learner Teacher Competency Enhancement Program Scenario}

The program starts from the learner teacher awareness efforts regarding the role of teachers as learners. From this awareness changes in attitude as a learner teacher are expected. The indicator is the rise of a willingness to learn and to develop their very own of potential. Next is the mastery of professional competence in which the indicator is the teacher is able to master the principles and procedures that support the disciplines of their teaching subjects. Then the mastery of pedagogy competence in which the indicator is that skilled teacher can manage learning in accordance with the characteristics of students depending on line, type and level of education. The final aim of the program is the improvement of teachers' performance and competence. The scenario of learner teacher program can be seen in the chart below:

TABLE I. SCENARIO'S IMPLEMENTATION OF LEARNER TEACHER PROGRAM

\begin{tabular}{|c|c|c|c|c|}
\hline & $\begin{array}{c}\text { Attitude } \\
\text { Changes as } \\
\text { Learner } \\
\text { Teacher } \\
\end{array}$ & $\begin{array}{l}\text { The Mastery of } \\
\text { Professional } \\
\text { competencies }\end{array}$ & \begin{tabular}{|c|} 
The Mastery of \\
Pedagogical \\
Competencies
\end{tabular} & \\
\hline Indicator & $\begin{array}{c}\text { Willingness to } \\
\text { learn and } \\
\text { develop } \\
\text { potential }\end{array}$ & $\begin{array}{l}\text { Mastering the } \\
\text { concept, principal, } \\
\text { and procedures that } \\
\text { support the disciplines } \\
\text { of teaching subjects }\end{array}$ & $\begin{array}{c}\text { Able to manage } \\
\text { learning in } \\
\text { accordance with } \\
\text { the } \\
\text { characteristics } \\
\text { of students } \\
\text { depending on } \\
\text { line, type and } \\
\text { level of } \\
\text { education }\end{array}$ & $\begin{array}{l}\text { The } \\
\text { Improvemen } \\
\text { t of } \\
\text { Teachers' } \\
\text { Competencie } \\
\text { s and } \\
\text { Performance }\end{array}$ \\
\hline $\begin{array}{l}\text { Matter o } \\
\text { Subject }\end{array}$ & $\begin{array}{l}\text { Self-reflection } \\
\text { as Learner } \\
\text { Teacher }\end{array}$ & $\begin{array}{l}\text { concept, principal, } \\
\text { and procedures that } \\
\text { support the disciplines } \\
\text { of teaching subjects }\end{array}$ & $\begin{array}{c}\text { Effective } \\
\text { learning } \\
\text { management }\end{array}$ & \\
\hline Activity & $\begin{array}{c}\text { Expository/Q } \\
\text { \&A/Discussio } \\
\text { ns }\end{array}$ & $\begin{array}{c}\text { Discussions, Tasks } \\
\text { Forums, Practical } \\
\text { Works }\end{array}$ & \begin{tabular}{|c|} 
Discussions, \\
Tasks Forums, \\
Practical Works \\
\end{tabular} & \\
\hline
\end{tabular}

\section{F. The Implications of Lifelong Learning towards Learner Teacher Program}

There's a saying that "Education is life, life is Education". The phrase stating that education is an indispensable part of human life, the reason of human existence is to be a creature of education (animal educandum), creatures that can be educated, have to be educated, and able to educate [6]. Humans can also be interpreted as hard-wired being which are programmed to learn in order to improve themselves [7]. Departing from such understanding, it can be interpreted as humans are individuals who continue to learn every in inch of their existence in the world, humans learn for their lifetime (lifelong learning). According Mudyahardjo [8], Lifelong Learning can be defined as education in the sense of immensity, Mudyahardjo confirms:

"In the sense of immensity, education means life. Education is all situations in life that affect one's development. Education is an experience of learning. Therefore, education can also be defined as the overall experience of each person throughout his life" [8]. 
According to Mudyahardjo it can be concluded that learning in the perspective of the vast education is a lifelong learning experience that creates history. The learning experience which creates history exists in an infinite dimension of space and time (Ibrahim, 2016, pg.37). The learning experience in the dimension of time is a learning experience of a lifetime, which begins early in life (from the womb) until one's death. While in the dimension of space, learning experience may be gained anywhere, learning experiences may be occurred in human-made socio-cultural communities such as residential, commercial communities, organizations, religious communities, and other social environments. The learning experience can also occur in the natural environment in which the result of God's creation of natural events such as the climate change, the change of day and night, the life cycle of flora and fauna, natural disasters and so on [8].

Besides that it is not limited by space and time, learning experience in the vast perspective of education is not limited by the shape of its activities. Education as a learning experience has diverse form, atmosphere, and patterns. Learning experience may be occurred at any time, perhaps even the mysterious events, such as for example: people are able to take lessons from any events that happen whether it is a fortune or misfortune. The forms of learning experience in a vast education perspective is able move in the range of atmosphere between the implicit lines, so it is not perceptible and can only be caught by the eyes of the heart or sense (all the bustle in the activities of life), until the atmosphere is very explicit so that the "what to do" in learning activities may be observed (all forms of programmed instruction). Education as an experience that is not limited in time, place, and form is random, means that it may occur anytime throughout the period of the age of life, anywhere in the environment, and at any time in the course of a human life, as well as anyone of mankind is a student, experience of life is a teacher, and the environment is lively places of learning or the school of mankind [8].

Based on the concept of lifelong learning as a form of education in the sense of immensity, learner teacher program is a manifestation of lifelong learning. With the learner teacher program, is expected that teachers in Indonesia to be able to be sensitized to continually improve their performance and competence as a professional in the field of education. Through learner teacher program it is expected that teachers may become magmatic, dialogical, participatory, and emancipatory.

\section{CONCLUSION}

Learner teacher program is a manifestation of lifelong learning. Through the program, learner teachers are expected to have a persistent attitude in developing its capacity as a learner. This persistence will implicate on the performance, and professional and pedagogical competence improvement. The goal of this program is the better social change in education. Because in essence teacher is a parameter of the advancement of education, therefore teachers should be magmatic, dialogical, participatory, and emancipatory.

\section{ACKNOWLEDGMENT}

The authors would like to thank the Directorate of HigherEducation, Ministry of Education and Culture of the Republic Indonesia, which has provided funding of this research.

\section{REFERENCES}

[1] Tilaar, H. (2012). Social Change and Education (Transformative Pedagogy for Indonesia). Jakarta : Rineka Cipta

[2] Morocco, C.C., et al. (2008) Supported Literacy for Adolescents: Transforming Teaching and Content Learning for The Twenty-First Century. San Francisco: Jossey-Bass A Wiley Imprint.

[3] Trilling, B. \& Fadel, C. (2009). 21st Century Skills: Learning for Life in Our Times. San Francisco: Jossey-Bass A Wiley Imprint.

[4] Binkley, M., et al. (2012) "Defining Twenty-First Century Skills" in Assessment and Teaching of 21st Century Skills. New York: Springer.

[5] Kemendikbud. (2016). Guru Pembelajar (Program Peningkatan Kompetensi). Jakarta : Kemendikbud

[6] Ibrahim, T (2016). Representasi Kesadaran Kritis Mahasiswa UPI pada Fenomena Pengalaman Belajar. (Studi Fenomenologi Pedagogik Paulo Freire). Bandung : Tesis (Tidak diterbitkan).

[7] Dewantara, K.H (2004). Pendidikan. Yogyakarta : Dewan Amanat Taman Siswa

[8] Mudyahardjo, R. (2001). The Philosophy of Educational Science. Bandung : Rosda 